\title{
Öğretmenlerin Örgütsel Destek Algılarının Okullarındaki İletişim İklimine Yönelik Algıları Üzerindeki Rolü*
}

\section{The Role of Teachers' Perceived Organizational Support on Their Perceptions of Communication Climate in Their Schools}

\author{
Sidıka GIZİR**, Merve FAKİROĞLU***
}

• Geliş Tarihi: 14.06.2019 • Kabul Tarihi: 15.07.2019 • Çevrimiçi Yayın Tarihi: 15.07.2019

\begin{abstract}
$\ddot{\mathbf{O} z}$
$\mathrm{Bu}$ araştırmanın amac1, öğretmenlerin öğretimsel, yönetsel ve adalet boyutlarında algıladıkları örgütsel desteğin okullarındaki iletişim iklimine yönelik algılarını yordayıp yordamadığını incelemektir. Çalışmanın örneklemini Hatay ili merkez ilçeleri olan Antakya ve Defne'deki ilkokul ve ortaokullarda görev yapmakta olan toplam 405 (222 kadın, 183 erkek) öğretmen oluşturmaktadır. Çalışmanın verileri Costigan ve Schmeidler (1987) tarafından geliştirilip Özden (2009) tarafindan Türkçeye uyarlanan "İletişim İklimi Envanteri” ile Çobanoğlu ve Derinbay (2011) tarafından geliştirilen "Algılanan Örgütsel Destek Ölçeği”" aracılığıyla elde edilmiştir. Verilerin analizinde çoklu regresyon analizi yöntemi kullanılmıştır. Elde edilen bulgular, algılanan örgütsel desteğin alt boyutlarından olan yönetimsel destek algısı ve adalet algısının, öğretmenlerin okullarındaki destekleyici ve savunmacı iletişim iklimi algısını yordayan önemli değişkenler olduğunu göstermektedir. Ancak, algılanan örgütsel desteğin alt boyutlarından olan öğretimsel desteğin ise öğretmenlerin iletişim iklimine yönelik algılarını yordayıcı bir değişken olmadığı görülmüştür. Söz edilen bulgular konu üzerine oluşan alanyazın dikkate alınarak tartışılmıştır.
\end{abstract}

Anahtar sözcükler: algılanan örgütsel destek, destekleyici iletişim iklimi, savunmacı iletişim iklimi.

Atıf:

Gizir, S. ve Fakiroğlu, M. (2020). Öğretmenlerin örgütsel destek algılarının okullarındaki iletişim iklimine yönelik algıları üzerindeki rolü. Pamukkale Üniversitesi Eğitim Fakültesi Dergisi, 48, 271-284. doi: 10.9779/pauefd.578125

\footnotetext{
* Bu çalışma 01-04 Kasım 2018 tarihinde Antalya'da düzenlenen 9. Uluslararası Eğitim Yönetimi Forumu'nda sözlü bildiri olarak sunulmuştur.

** Doç. Dr., Mersin Üniversitesi, Eğitim Fakültesi, Eğitim Bilimleri Bölümü, Mersin, e-posta: sgizir@gmail.com, https://orcid.org/0000-0003-4071-8220

*** Öğretmen, MEB; Mersin Üniversitesi, Eğitim Bilimleri Enstitüsü, Eğitim Yönetimi ABD. yüksek lisans öğrencisi, e-posta: mfakiroglu04@gmail.com, https://orcid.org/0000-0003-2609-9718
} 


\begin{abstract}
The present study aims to examine the extent to which teachers' perceived organizational support regarding instructional support, administrative support and justice predicted their perceptions on communication climate in their schools. The sample of this study consisted of 405 (222 female, 183 male) primary and secondary school teachers in Antakya and Defne districts of Hatay province in Turkey. The data of the study were obtained through "Communication Climate Inventory" which is developed by Costigan and Schmeidler (1987) and adapted into Turkish by Özden (2009), and "Perceived Organizational Support Scale" developed by Çobanoğlu and Derinbay (2011). Multiple regression analysis was used to analyze the data. The results showed that perceived administrative support and justice as sub-dimensions of perceived organizational support were important predictive variables of teachers' perceived supportive and defensive communication climate in their schools. However, it was observed that instructional support was not a predictive variable of teachers' perceived communication climate. The results obtained are discussed by considering the related literature.
\end{abstract}

Keywords: perceived organizational support, supportive organizational climate, defensive, communication climate.

\title{
Cited:
}

Gizir, S., \& Fakiroğlu, M. (2020). The role of teachers' perceived organizational support on their perceptions of communication climate in their schools. Pamukkale Üniversitesi Eğitim Fakültesi Dergisi, 48, 271-284.doi:10.9779/pauefd.578125 


\section{Giriş}

Örgüt çalışanlarının tutum, değer, inanç ve davranışları arasında uyum sağlamaya yönelik ortak eğilimleri yansıtma süreci olarak tanımlanan iletișim, çalışanların yaptıkları ișe ve ortama anlam yüklemelerini sağlamakta ve örgütsel gerçekliğe yönelik algılarını şekillendirmektedir (Gizir, 2007; Gizir ve Köksal, 2014; Kowalski, 2000). Bu yönüyle sembolik bir süreç olarak görülen iletişim, çalışanların kendi aralarında etkileşimde bulunmalarını sağlayarak birbirlerinin algı, tutum ve davranışlarını oluşturma, yönlendirme ve değiştirmelerine olanak tanımaktadır (Book, Albrecht, Atkin, Bettinghaus ve Donohue, 1980; Çetin, 2012). Bu kapsamda, çalışanların örgütlerinin iç çevresini ve örgütteki yaşantılarını öznel olarak deneyimledikleri ileri sürülmektedir. Dennis (1975, akt. Guzley, 1992), çalışanların formal ve informal iletişim sürecinde mesajların içerikleri, mesajların yönü ve biçimi ile bu süreçte ortaya çıkan olaylarla ilgili kişisel algılarını anlamlı bir biçimde tanımlandıklarını belirterek, böylece örgütlerin iletişim ikliminin oluştuğunu ifade etmektedir. Robertson (2003) ise iletişim ikliminin örgüt çalışanları arasındaki karşılıklı ilişki, iletişim ve etkileşim ile her bir yönetim sürecinde kendini gösteren bir çeşit atmosfer olduğunu ileri sürmektedir. Alanyazın incelendiğinde, iletişim ikliminin, çalışanların ne hissettikleri, örgüt içindeki etkileşimlerinin nasıl olduğu, örgüt içi iletişim davranışları, yöneticilerin çalışanlarıyla kurduğu iletişim üslubu ve ekip çalışmalarının nasıl gerçekleştiğine ilişkin çalışanların ortak algısını işaret ettiği görülmektedir (Özden ve Gizir, 2013; Özden, 2009; Robertson, 2003). Örgüt içerisinde oluşan iletişim iklimi ayrıca fiziksel olarak oluşan iklim metaforuyla da temsil edilmekte; nasıl bir bölgenin iklimini belirleyen şey hava olayları ise örgütlerin iklimi de insanların tepki verme biçimiyle oluşmaktadır (Ahsanul, 2013).

İlgili alanyazında, bu kavramın çeşitli yaklaşımlara göre çeşitli şekillerde sınıflandırıldığı ve buna göre de içerdiği boyutların farklılaştığı görülmektedir. Örneğin Hussein ve Mohammed (2013) iletişim iklimini, örgütsel iklimin bir alt boyutu olarak görürken, Welsh ve LaVan (1981) bu iklimin örgütsel iklimden bağımsız olduğunu ileri sürmektedir. Etkileşimci yaklaşım ise iletişim ikliminin sosyal ve psikolojik içeriğe sahip olduğuna, dolayısıyla bireysel ve grup olmak üzere farklı düzeyde ele alınabileceğine vurgu yapmaktadır (Smidts, Pruyn ve Van Riel, 2001). Bunu yanı sıra Buchholz (2001), iletişim iklimini açık ve kapalı olarak sınıflandırmaktadır. Bilginin serbestçe aktığı ortamlarda iletişim ikliminin açık, bilgi akışının engellendiği ortamlarda ise kapalı olduğu belirtilmekte ve iletişimin açık olduğu ortamda çalışanların fikirlerini bildirmekten, üstlerine şikayetlerini sunmaktan çekinmeyecekleri, aksi takdirde ise kaygılarını özgürce belirtemeyeceklerinden söz edilmektedir. Bununla birlikte, konuyla ilgili oluşan alanyazında, iletişim ikliminin sıklıkla destekleyici ve savunmacı iletişim iklimi olarak iki tip ya da boyut olarak ele alındığı görülmektedir (Forward, Czech ve Lee, 2011; Gibb, 1961; Gül, 2012; Özden ve Gizir, 2013; Ulukuş, 2010). Her bir iletişim iklimi tipi ya da boyutu belirli iletişim davranışlarını içermektedir. Destekleyici iletişim iklimine sahip örgütlerde çalışanların katılımının desteklendiği, örgütlerin açık bir iklime sahip olduğu, uyuşmazlıkların çözüldüğ̈̈ bir yapının hakim olduğu görülürken; savunmacı iletişim iklimine sahip olan örgütlerde çalışanların birçok şeyi sakladıkları, mevcut durumu korumaya çalıştıkları, çalışanlarının kaygılı ve morallerinin genel anlamda düşük olduğu görülmektedir (Forward, Czech ve Lee, 2011; Gül, 2012; Hassan, Maqsood ve Riaz, 2011). Benzer olarak destekleyici iletişim iklimi tanımlayıcı, esneklik, empati kurma, problem odaklı, doğal ve eşitlikçi davranışlardan oluşurken; savunmacı iletişim iklimi ise strateji, kontrol, değerlendirme, kesinlik ve üstünlük sağlamaya yönelik tutum ve davranışları içermektedir (Gül, 2012; Hassan, Maqsood ve Riaz, 2011; Özden, 2009; Ulukuş, 2010).

İletişim iklimi üzerine yapılan çalışmalar incelendiğinde, bu iklimin iş doyumu, çatışma, bağl1lık, performans, örgüt iklimi, verimlilik, güven ve motivasyon benzeri birçok örgütsel davranışla ilişkilendirildiği görülmektedir (Buchholz, 2001; Robertson, 2003; Trobbetta 
ve Rogers, 1988). İletişim ikliminin yanı sıra ilgili alanyazında, çalışanların işlerini ilgi, sevgi ve yüksek motivasyonla yapmaları, örgütlerine bağl1lık göstermeleri, örgütsel kimlik geliştirmeleri ve dolayısıyla yüksek performans göstermelerinde ait olma, onay ve saygı görme, değerli olduğunu hissetme ve işlerini yaparken desteklendiğini hissetme gibi ihtiyaç ve beklentilerinin örgütleri tarafından karşılanmasının önemli olduğu vurgulanmakta; bu beklenti ve ihtiyaçların karşılanmasına ilişkin oluşan çalıșan algısının ise örgütsel destek algısı olduğu belirtilmektedir (Eğriboyun, 2013; Fındıkl1, 2014; Ökten, 2015). Aselage ve Eisenberger (2003), örgütsel destek algısını, çalışanın çalıştığı örgütle yapmış olduğu psikolojik anlaşma olarak değerlendirmektedir. $\mathrm{Bu}$ anlaşmanın yerine getirilmesiyle örgütün işverene yeterli hizmet ve yararları sunacağı, buna bağlı olarak çalışanın da olumlu tutum ve iş davranışlarını örgütsel ortamda sergileyeceği ifade edilmektedir (Barutçu, 2015; Büyükgöze, 2014; Eğriboyun, 2013; Yüksel, 2006). Dolayısıyla, çalışanların örgütleri tarafından destek görmesi kadar onların desteklendiklerini, değerli ve önemli olduklarını hissetmeleri, diğer bir ifadeyle örgütlerinden destek gördükleri bir algısına sahip olmaları gerekmektedir. Eğriboyun (2013) da örgütünden destek aldığına yönelik algısı olan çalışanların örgütlerine faydalı olacak davranışları daha fazla sergileyeceğini, çünkü bu desteği alan bireylerin ait olma, saygı ve onaylanma ihtiyaçlarının karşılandığını ifade etmektedir. Demir (2012) ise çalışanların iş sürecinde en uygun kararı alabilmesi, olası hataların engellenmesi için örgütsel düzeyde sürekli ve sistematik olarak desteklenmeleri gerektiğini ifade etmektedir. Ayrıca desteklenen birey, görev, sorumluluk ve yetkileriyle ilgili rolleri iyice benimseyerek işine ve örgüte bağlanmaktadır.

Benzer şekilde Ökten (2015), yöneticilerin çalışanlara ve onların emeklerine değer vermeleri, iyilik ve mutluluklarını düşünmelerinin ve çalışanlarına çeşitli tutum ve davranışlarla bunu hissettirmelerinin çalışanların istendik yönde birçok olumlu davranış sergilemelerine yol açacağını, çalışanların örgütlerini sahipleneceğini ifade etmektedir. Bunun yanı sıra Turgut (2014) ise örgütsel destek algısının, çalışanların performansı, işe geç kalma(ma), işten ayrılma niyetleri, işi yavaşlatma ve iş doyumlarında olumlu yönde etkili olduğunu dile getirmektedir. Çalışanların örgütlerinde bu yönde deneyimler edinmesi ve algı geliştirmelerinin, diğer örgütsel süreçlere ve temalara yönelik tutum ve algılarıyla ilişkilendirilebileceği düşünülmektedir. Nitekim daha önce de belirtildiği gibi sözü edilen yaşantıları içeren süreçler aracılığıyla çalışanlar yaptıkları işe ve ortama anlam yüklemekte ve örgütsel gerçekliğe yönelik algıları şekillenmektedir (Gizir, 2007; Kowalski, 2000). Diğer bir ifadeyle bireysel olarak sahip olunan alg1 ve tutumlar, çalışanlar arası etkileşimle örgüt içerisinde ortak alg1, tutum ve davranışa dönüşerek iklimin oluşması ya da şekillenmesine neden olmaktadır. Bu kapsamda çalışanların örgütleri tarafindan desteklenmesi, bu desteği ve değerli olduklarını hissetmeleri, saygı gördüklerine ve onaylandıklarına yönelik algı geliştirmeleri oldukça önemlidir. Çünkü bu algının, onların genel olarak örgüt içerisinde kişiler arası etkileşim ve iletişime yönelik ortak alg1 ve davranışları işaret eden iletişim iklimiyle ilişkilendirilebileceği düşünülmektedir. $\mathrm{Bu}$ çalışma kapsamında yapılan alanyazın incelemesi sonucunda öğretmenlerin örgütsel destek algısına yönelik çeşitli çalışmalar olduğu gözlenmiştir (Büyükgöze, 2014; Çobanoğlu ve Derinbay, 2011; Eğriboyun, 2013). Benzer şekilde çalışanların örgütlerindeki iletişim iklimine yönelik algılarının, diğer örgütsel ve yönetsel süreçlere yönelik algı ve tutumlarıyla yakından ilişkili olduğu sıklıkla vurgulanmasına rağmen, özellikle öğretmenlerin okullarındaki iletişim iklimine yönelik algılarını ele alan sınırlı sayıda çalışma olduğu görülmüştür. Bununla birlikte öğretmenlerin örgütsel destek algısıyla iletişim iklimiyle ilişkilendiren herhangi bir çalışmaya ise rastlanmamıştır. $\mathrm{Bu}$ bilgiler temelinde, bu çalışmada öğretmenlerin örgütsel destek algılarının okullarındaki iletişim iklimine yönelik algıları üzerindeki rolü belirlenmeye çalışı1mıştır.

Eğitim örgütleri olarak okul ortamında algılanan örgütsel destek yönetsel destek, öğretimsel destek ve adalet olmak üzere üç alt boyutta ele alınmaktadır. Öğretimsel destek, öğretmenlerin öğretim sürecine ilişkin mesleki gelişim, kaynak ve materyal gibi ihtiyaçların ne 
derece karşılandığı konusundaki görüşlerini işaret etmektedir. Yönetsel destek, öğretmenlerin duygusal, bilgisel ve maddi destek konusundaki görüşlerini ifade ederken; adalet ise öğretmenlerin, okul yönetiminin adil davranması konusundaki görüşlerini içermektedir (Derinbay, 2011). Bu çalışma kapsamında öğretmenlerin algıladıkları örgütsel destek, sözü edilen bu üç boyutta ele alınarak onların okullarındaki iletişim iklimine yönelik algılarını (destekleyici ve savunmacı iletişim iklimi) yordayıp yordamadığını belirlemek amaçlanmıştır. $\mathrm{Bu}$ amaca doğrultusunda aşağıdaki araştırma sorularına yanıt aranmıştır:

1. Kamu ilköğretim okullarında görev yapan öğretmenlerin öğretimsel, yönetimsel ve adalet boyutlarında örgütsel destek algıları okullarındaki savunmacı iletişim iklimini yordamakta midir?

2. Kamu ilköğretim okullarında görev yapan öğretmenlerin öğretimsel, yönetimsel ve adalet boyutlarında örgütsel destek algıları okullarındaki destekleyici iletişim iklimini yordamakta midır?

\section{Yöntem}

\section{Araştırma Deseni}

Hatay ili merkez ilçelerinde çalışan ilköğretim öğretmenlerinin öğretimsel destek, yönetsel destek ve adalet boyutlarında algıladıkları örgütsel desteğin öğretmenlerin algıladıkları iletişim iklimini yordayıp yordamadığının belirlenmeye çalışıldığı bu araştırmada, var olan durumu betimlemek amacıyla ilişkisel tarama modeli kullanılmıştır.

\section{Evren ve Örneklem}

Bu çalışmanın evreni, Hatay ilindeki çeşitli kamu ilkokul ve ortaokullarında görev yapmakta olan 4281 öğretmenden oluşmaktadır. Defne ilçesinde 45 ilkokul ve 560 ilkokul öğretmeni; 32 ortaokul ve 574 ortaokul öğretmeni bulunmaktadır. Antakya ilçesinde ise 75 ilkokul ve 1309 ilkokul öğretmeni; 77 ortaokul ve 1838 ortaokul öğretmeni görev yapmaktadır. Çalışmanın örneklemi ise araştırma amacı, değişkenlerin özellikleri ve çalışma evrenin büyüklüğü dikkate alınarak evrenden katmanlı seçkisiz örnekleme yoluyla belirlenmiştir. Bu kapsamda yapılan hesaplamalar sonucunda 105'i Defne, 245'i Antakya ilçesinde olmak üzere toplam 350 ilkokul öğretmeni ile 107'si Defne, 343'ü Antakya ilçesinden olmak üzere toplam 450 ortaokul öğretmenine uygulama yapılmıştır. 27 ilkokul ve 25 ortaokul olmak üzere toplam 800 öğretmene uygulama yapılmış ancak 598 tanesi geri dönmüştür. Eksik ve yanlış doldurulan ölçekler analize dahil edilmemiştir. Sonuç olarak, örneklemi oluşturan 405 öğretmenin 69'u Defne, 98'i Antakya ilçesinden olmak üzere toplam 167'si ilkokul öğretmeni; 81'i Defne ve 157'si Antakya ilçesinden olmak üzere toplam 238'i ortaokul öğretmenidir. Örneklem 222'si (\% 54.8) kadın, 183'ü (\%45.2) ise erkektir. Tablo 1'de sunulduğu gibi örneklemin 115'i (\%28.4) sinif, 39'u (\%9.6) matematik, 37'si (\%9.1) fen bilimleri, 40’1 (\%9.9) İngilizce, 51'i (\%12.6) Türkçe, 27'si (\%6.7) sosyal bilimler, 36'sı (\%8.9) din kültürü ve 60'ı (\%14.8) diğer branşlardan olan öğretmenlerdir. Ayrıca 1-5 y1l arası görev yapan öğretmen sayısı 102 (\%25.2), 6-10 yıl aras1 görev yapan öğretmen sayıs1 57 (\%14.1), 11-15 y1l aras1 görev yapan öğretmen sayıs1 89 (\%22), 16-20 yıl aras1 görev yapan öğretmen sayıs1 79 (\%19.5) ve 21 y1l ve üzeri görev yapan öğretmen sayısı ise $78^{\prime}$ dir (\%19.3). 
Tablo 1. Örneklemin Branş, Hizmet Yılı ve Cinsiyete Göre Dağılımı

\begin{tabular}{|c|c|c|c|c|c|c|c|c|c|c|c|c|c|}
\hline \multirow{2}{*}{ Branşlar } & \multicolumn{2}{|c|}{$1-5 Y_{1}$} & \multicolumn{2}{|c|}{ 6-10 Y1l } & \multicolumn{2}{|c|}{$11-15 Y_{11}$} & \multicolumn{2}{|c|}{$16-20 Y_{11}$} & \multicolumn{2}{|c|}{21 Üzeri } & \multicolumn{2}{|c|}{$\begin{array}{l}\text { Gruplar } \\
\text { Toplamı }\end{array}$} & \multirow{2}{*}{$\begin{array}{l}\text { Genel } \\
\text { Toplam }\end{array}$} \\
\hline & $\mathrm{K}$ & $\mathrm{E}$ & $\mathrm{K}$ & $\mathrm{E}$ & $\mathrm{K}$ & $\mathrm{E}$ & $\mathrm{K}$ & $\mathrm{E}$ & $\mathrm{K}$ & $\mathrm{E}$ & $\mathrm{K}$ & $\mathrm{E}$ & \\
\hline Matematik & 14 & 2 & 3 & 2 & 3 & 6 & 2 & 4 & 1 & 2 & 23 & 16 & 39 \\
\hline Fen & 11 & 0 & 2 & 0 & 2 & 5 & 0 & 4 & 4 & 9 & 19 & 18 & 37 \\
\hline İngilizce & 10 & 0 & 8 & 2 & 7 & 7 & 2 & 3 & 0 & 1 & 27 & 13 & 40 \\
\hline Türkçe & 11 & 1 & 5 & 1 & 7 & 11 & 4 & 9 & 1 & 1 & 28 & 23 & 51 \\
\hline Sosyal & 2 & 3 & 0 & 5 & 1 & 1 & 5 & 7 & 0 & 3 & 8 & 19 & 27 \\
\hline Sinif & 9 & 1 & 14 & 4 & 13 & 8 & 15 & 11 & 14 & 26 & 65 & 50 & 115 \\
\hline DinKültürü & 16 & 0 & 2 & 0 & 5 & 3 & 0 & 1 & 0 & 9 & 23 & 13 & 36 \\
\hline Diğer & 13 & 9 & 3 & 6 & 5 & 5 & 6 & 6 & 2 & 5 & 29 & 31 & 60 \\
\hline Toplam & 86 & 16 & 37 & 20 & 43 & 46 & 34 & 45 & 22 & 56 & 222 & 183 & - \\
\hline G. Toplam & & & & & & & & & & & & & 405 \\
\hline
\end{tabular}

\section{Veri Toplama Araçları}

\section{İletişim iklimi envanteri}

Costigan ve Schmeidler (1987) tarafından geliştirilen ve Özden (2009) tarafindan ilköğretim okullarındaki farklı branşlardan öğretmenlerin oluşturduğu örneklem ile Türkçeye uyarlanan "İletişim İklimi Envanteri” (İIE), destekleyici ve savunmacı iletişim iklimi olmak üzere iki alt ölçekten oluşmakta ve toplam 36 madde içermektedir. Destekleyici iletişim iklimi alt ölçeği faktör yükleri .651 ile .909 arasında değişen toplam 18 maddeden oluşmakta ve Cronbach alfa iç tutarlılık katsayısının .97'dir (Özden, 2009). Benzer şekilde, savunmacı iletişim iklimi alt ölçeği ise faktör yükleri .483 ile .882 arasında değișen toplam 18 maddeden oluşmaktadır ve Cronbach alfa iç tutarlılık katsayısı 96 olarak belirlenmiştir (Özden, 2009). Özden (2009) her iki alt ölçeğin kuramsal olarak altışar alt boyuta sahip (destekleyici iletişim iklimi problem odakl1, tanımlayıcı, kendiliğinden, eşitlik, empatik, esneklik boyutlarını; savunmacı iletişim iklimi ise kontrol, strateji, değerlendirme, tarafsızlık, kesinlik, üstünlük boyutlarını içermektedir) olmasına rağmen faktör analizi sonucunda her bir alt ölçeğin tek faktörlü bir yapıya sahip olduğunu belirtmektedir. Bu ölçme aracının çeşitli çalışmalarda kullanıldığ 1 ve benzer şekilde savunmacı ve destekleyici iletişim iklimi olmak üzere her iki alt ölçeğin tek boyutlu yapıda olduğu gözlenmiştir (Hassan, Maqsood ve Riaz, 2011; Keenan, 1988; Larsen ve Folegro, 1993). Bunun yanı sıra bu çalışma kapsamında yapılan analiz sonucunda destekleyici iletişim iklimi alt ölçeğinin Cronbach alfa iç tutarlılık katsayısının .82; savunmacı iletişim iklimi alt ölçeğinin ise. 79 olduğu belirlenmiştir.

\section{Algılanan örgütsel destek ölçeği}

Öğretmenlerin örgütsel destek algısına yönelik veri Çobanoğlu ve Derinbay (2011) tarafından geliştirilen "Algılanan Örgütsel Destek Ölçeği” (AÖDÖ) aracılığıyla elde edilmiş̧tir. Bu ölçme arac1 öğretimsel destek, yönetsel destek ve adalet olmak üzere üç alt boyut içermekte olup toplam 29 maddeden oluşmaktadır. Çobanoğlu ve Derinbay (2011) öğretimsel destek alt boyutunun 9 maddeden oluştuğunu ve Cronbach alfa iç tutarlılık katsayısının .83 olduğunu; 9 maddeden oluşan yönetsel destek alt boyutunun Cronbach alfa iç tutarlılık katsayısının .89 olduğunu ve 11 maddeden oluşan adalet alt boyutunun ise Cronbach alfa iç tutarlılık katsayısının .92 olduğunu belirtmektedir. Ayrıca, bu üç alt boyutun faktör yükleri 39 ile .76 arasında değişmektedir (Derinbay, 2011). Bu çalışmada ise ölçeğin öğretimsel destek alt boyutunun Cronbach alfa iç tutarlılık katsayısının .71; yönetsel destek alt boyutunun .76 ve adalet alt boyutunun ise .79 olduğu belirlenmiştir. 


\section{Veri Analizi}

Verilerin analizinde öncelikle çoklu regresyon analizi sayıltıları incelenmiştir. Bu kapsamda, kullanılan ölçme araçlarının puanlarının normal dağılıp dağılmadığ değişkenler (öğretimsel, yönetimsel ve adalet) ile yordanan değişken (destekleyici ve savunmac1 iletişim iklimi) arasında doğrusal bir ilişki olup olmadığı SPSS programında saçılma diyagramı ile incelenmiştir. Ardından Mahanolobis testi sonuçları da dikkate alınarak, değişkenler arasındaki Pearson Korelasyon Katsayıları hesaplanmıştır. Son olarak, öğretmenlerin öğretimsel, yönetimsel ve adalet boyutlarında örgütsel adalet algılarının, onların okullarındaki destekleyici ve savunmacı iletişim iklimini yordayıp yordamadığını belirlemek için çoklu regresyon analizi yapılmıştır. Araştırmada anlamlılık düzeyi .01 olarak kabul edilmiştir.

\section{Bulgular}

$\mathrm{Bu}$ araştırmanın örneklemini oluşturan öğretmenler için yordanan değişken iletişim iklimi algısı (destekleyici iletişim iklimi, savunmacı iletişim iklimi) ile yordayıcı değişken olan algılanan örgütsel destek (öğretimsel destek, yönetsel destek, adalet) arasındaki Pearson korelasyon katsayıları Tablo 2'de sunulmuştur. Araştırma bulgularına göre ilgili değişkenler arasında istatistiksel açıdan anlamlı ilişkiler gözlemlenmektedir. Bu ilişkilerin değerlendirilmesinde Cohen'in (1992) belirlediği etki gücünün standart puanlaması kriterleri kullanılmıştır. Buna göre değişkenler arasındaki korelasyonlarda .10 düşük düzey, .30 orta düzey ve .50 yüksek düzey ilişki olarak tanımlanmıştır.

Tablo 2. Değişkenler Arasındaki Korelasyonlar ile Değişkenlerin Aritmetik Ortalama ve Standart Sapması $(\mathrm{N}=405)$

\begin{tabular}{lccccc}
\hline \multicolumn{1}{c}{ Değişkenler } & $\mathbf{1}$ & $\mathbf{2}$ & $\mathbf{3}$ & $\mathbf{4}$ & $\mathbf{5}$ \\
\hline 1. Destekleyici İletişim İklimi & - & & & & \\
2. Savunmacı İletişim İklimi & $-.635^{* *}$ & - & & & \\
3. Öğretimsel Destek & $.329^{* *}$ & $-.167^{* *}$ & - & & \\
4. Yönetsel Destek & $.598^{* *}$ & $-.481^{* *}$ & $.405^{* *}$ & - & \\
5. Adalet & $.585^{* *}$ & $-.485^{* *}$ & $.374^{* *}$ & $.728^{* *}$ & - \\
\hline Aritmetik Ortalama & 34.921 & 68.024 & 24.321 & 17.535 & 21.303 \\
Standart Sapma & 10.373 & 10.515 & 3.064 & 6.149 & 7.528 \\
\hline
\end{tabular}

$* \mathrm{p}<.01$

Analiz sonucunda Tablo 2'de sunulduğu üzere Cohen'in (1992) kriterleri açısından incelendiğinde, öğretimsel destek algisı ile destekleyici iletişim iklimi algisı arasında orta düzeyde pozitif yönlü $(\mathrm{r}=.329, \mathrm{p}<.01)$; savunmacı iletişim iklimi algısıyla ise $(\mathrm{r}=-.167, \mathrm{p}<.01)$ negatif yönlü anlamlı bir ilişki olduğu bulgusuna ulaşılmıştır. Bununla birlikte öğretmenlerin yönetsel destek algılarıyla destekleyici iletişim iklimi algıları arasında $(\mathrm{r}=.598, \mathrm{p}<.01)$ yüksek düzeyde pozitif yönlü anlamlı bir ilişki gözlemlenirken, savunmacı iletişim iklimi algılarıyla $(\mathrm{r}=-.481, \mathrm{p}<.01)$ orta düzeyde negatif yönlü anlamlı bir ilişki gözlenmiştir. Bunun yanı sıra öğretmenlerin adalet algılarıyla destekleyici iletişim iklimi algıları arasında yüksek düzeyde pozitif yönlü $(\mathrm{r}=.585, \mathrm{p}<.01)$; savunmacı iletişim iklimi algılarıyla ise $(\mathrm{r}=-.485, \mathrm{p}<.01)$ orta düzeyde negatif yönlü anlamlı bir ilişki olduğu bulgusuna ulaşılmışırı. Ayrıca analiz sonucunda toplam puan ortalamalarının destekleyici iletişim iklimi için $\bar{X}=34.92$; savunmacı iletişim iklimi için $\bar{X}=68.02$ ve örgütsel destek algısı ölçeğinin alt boyutları olan öğretimsel destek için $\bar{X}=24.32$; yönetimsel destek algısı için $\bar{X}=17.54$ ve adalet algısı için ise $\bar{X}=25.30$ olduğu belirlenmiştir. 


\section{Destekleyici ve Savunmacı İletişim İklimi Algısını Yordayan Değişkenler}

İlköğretim okullarında çalışan öğretmenlerin okullarındaki destekleyici iletişim iklimine yönelik algılarının yordayıcıları olarak öngörülen öğretimsel destek algısı, yönetsel destek algısı ve adalet algısına yönelik çoklu regresyon analizi sonuçları Tablo 3 'te sunulmuştur. Analizi sonucunda, yönetsel destek ve adalet alt boyutlarının, öğretmenlerin çalıştığ 1 okullardaki destekleyici iletişim iklimi algılarını anlamlı düzeyde yordadıklarını $\left(F_{(3,401)}=92.709, p<.01\right.$, $\left.R=.64, R^{2}=.41\right)$ ve sözü edilen bu değişkenlerin açıklanan varyansa katkısının \%41 olduğu belirlenmiştir. Diğer yandan öğretimsel destek algısının ise destekleyici iletişim iklimi algısını istatistiksel açıdan anlamlı düzeyde yordamadığı bulgusuna ulaşılmıştır $(\beta=.075 ; t=1.780$, $p=.076)$. Standardize edilmiş regresyon katsayıları $(\beta)$ dikkate alındığında, yordayıcı değişkenlerin destekleyici iletişim iklimi üzerinde göreli önem sırası yönetsel destek $(\beta=.345$; $t=6.025, p=.000)$, adalet $(\beta=.306 ; t=5.421, p=.000)$ şeklindedir.

Tablo 3. Destekleyici İletişim İkliminin Yordayıcı Değişkenlerine İlişkin Çoklu Regresyon Analizi Sonuçları (N=405)

\begin{tabular}{lccccccc}
\hline \multicolumn{1}{c}{ Değişkenler } & $\mathbf{B}$ & $\mathbf{S H}_{\mathbf{B}}$ & $\boldsymbol{\beta}$ & $\boldsymbol{t}$ & $\boldsymbol{p}$ & $\mathbf{R}$ & $\mathbf{R}^{\mathbf{2}}$ \\
\hline Sabit & 9.550 & 3.189 & & 2.995 & .003 & & \\
Öğretimsel Destek & .255 & .143 & .075 & 1.780 & .076 & & \\
Yönetsel Destek & .581 & .097 & .345 & 6.025 & .000 & & .41 \\
Adalet & .421 & .078 & .306 & 5.421 & .000 & & \\
\hline
\end{tabular}

$\mathrm{F}_{(3-401)}=92.709, p<.01$

Öğretmenlerin okullarındaki savunmacı iletişim iklimine yönelik algılarının yordayıcıları olduğu düşünülen öğretimsel destek algısı, yönetsel destek algısı ve adalet algısına yönelik çoklu regresyon analizi sonuçları ise Tablo 4'de sunulmuştur. Analizi sonucunda elde edilen bulgulara göre, öğretmenlerin yönetsel destek ve adalet algılarının, okullarındaki savunmacı iletişim iklimine yönelik algılarını anlamlı düzeyde yordamakta $\left(F_{(3,401)}=50.284\right.$, $p<.01, R=.52, R^{2}=.27$ ) ve bu sözü edilen değişkenlerin açıklanan varyansa katkıs1 \%27'dir. Diğer yandan öğretimsel destek algısının savunmacı iletişim iklimi algısını istatistiksel açıdan anlamlı düzeyde yordamadığ edilmiş regresyon katsayıları $(\beta)$ dikkate alındığında, yordayıcı değişkenlerin savunmacı iletişim iklimi algısı üzerinde göreli önem sırası yönetsel destek $(\beta=-.495 ; t=-4.558, p=.000)$, adalet $(\beta=-$ $.416 ; t=-4.764, p=.000)$ şeklindedir.

Tablo 4. Savunmacı İletişim İkliminin Yordayıcı Değişkenlerine İlişkin Çoklu Regresyon Analizi Sonuçları $(N=\mathbf{4 0 5})$

\begin{tabular}{lccccccc}
\hline \multicolumn{1}{c}{ Değişkenler } & $\mathbf{B}$ & $\mathbf{S H}_{\mathbf{B}}$ & $\boldsymbol{\beta}$ & $\boldsymbol{t}$ & $\boldsymbol{p}$ & $\mathbf{R}$ & $\mathbf{R}^{2}$ \\
\hline Sabit & 80.378 & 3.586 & & 22.416 & .000 & & \\
Öğretimsel Destek & .213 & .161 & .062 & 1.324 & .186 & & \\
Yönetsel Destek & -.495 & .109 & -.289 & -4.558 & .000 & & .27 \\
Adalet & -.416 & .087 & -.298 & -4.764 & .000 & & \\
\hline
\end{tabular}

$\mathrm{F}_{(3-401)}=50.284, p<.01$ 


\section{Tartışma ve Sonuç}

$\mathrm{Bu}$ araştırmada, ilköğretim okullarındaki öğretmenlerin öğretimsel, yönetsel ve adalet boyutlarında örgütsel destek algılarının okullarındaki iletişim iklimine yönelik algılarını yordayıp yordamadığı belirlenmeye çalışılmıştır. Araştırma bulguları, algılanan örgütsel desteğin alt boyutları olan yönetsel destek ve adalet değişkenlerinin öğretmenlerin okullarındaki iletişim iklimine ilişkin algılarını yordayan önemli değişkenler olduğunu göstermiştir. Buna karşın ögretimsel destek alt boyutunun ise öğretmenlerin okullarındaki iletişim iklimine ilişkin algılarını anlamlı düzeyde yordamadığı görülmektedir.

Bununla birlikte algılanan örgütsel desteğin tüm alt boyutlarıyla destekleyici iletişim iklimi arasında pozitif yönlü anlamlı bir ilişki olduğu görülmüştür. Destekleyici iletişim iklimi ile en yüksek düzeyde ilişkinin ise yönetsel destek algısıyla olduğu belirlenmiştir. Algılanan yönetsel destek, okul yönetiminin öğretmenlerin problemleriyle ilgilenmesi, öğretmenin kendini mutlu hissetmesi için çabalaması, okul ile ilgili konularda öğretmene rehberlik etmesi, öğretmenler ve diğer çalışanlar arasında ilişki ve işbirliğinin gelişmesi için çaba göstermesi, gerektiğinde öğretmenlerini savunması, yöneticilerin öğretmenlerin eleştiri ve önerilerine açık olmasını içermektedir (Derinbay, 2011; Eğriboyun, 2013). Öğretmenlerin okulları ve okul yönetimine ilişkin bu yönde algı sahibi olmalarının, karşılıklı güven, saygı ve empatinin söz konusu olduğu, bütün çalışanların görüşlerinin önemli ve değerli olduğunun kabul edildiği, öğretmenlerin örgütsel süreçlere katılımının desteklendiği, problemlerin çözümünde işbirliği içerisinde davranmaya yönlendirildiği, açık ve dürüst bir iletişim ortamının olduğu bir iletişim iklimine (Gül, 2012; Hassan, Maqsood ve Riaz, 2011; Özden, 2009; Ulukuş, 2010) yönelik alg1 geliştirmeleri kabul edilebilir bir bulgu olarak görülmektedir. Benzer şekilde, Bilir (2005) çalışanların örgüt tarafından desteklendiklerine yönelik algılarının olmasının örgütün amaç, beklenti ve sorunları ile ilgilenmeleri ve sahiplenmeleri, sorumluluklarını bilinçli bir biçimde yerine getirmeleri, kişisel ödül beklentisi olmaksızın örgüt için çalışma gayretine girdiklerini belirtmekte ve bu durumun destekleyici bir iklimi işaret eden açı ve samimi ilişkilerin, işbirliğinin, sosyalleşmenin, dostluğun, kişisel özgürlük ile kişilerarası ve yöneticilere olan güvenin söz konusu olduğu bir iklimle ilişkili olduğunu belirtmektedir.

Diğer yandan öğretmenlerin yönetsel destek algısı ile savunmacı iletişim iklimi arasında yüksek düzeye yakın negatif yönlü bir ilişki olduğu ve bu algının savunmacı iletişim iklimini yordayan önemli bir değişken olduğu belirlenmiştir. Destekleyici iletişim ikliminin aksine savunmacı iletişim iklimi, örgüt içi değerlendirmelerin yargılamaya dayalı ve kaba bir şeklinde yapıldığı, öğretmenlerin kararlara katılmadığı, aksine önceden verilen kararlara katılmaya zorlandıkları, diğer bir ifadeyle manipülasyon ve zorlamanın olduğu, öğretmenlerin kaygılı olduğu, iletişim süreci ve içeriğinin yönetimin kontrolünde olduğu, öğretmenlere sayg1 gösterme ve güven verme ihtiyacının hissedilmediği, öğretmenlerin görüşlerinin önemli olmadığı ve onların kendilerini yetersiz hissetmelerine yol açan sınırlı bir iletişim sürecinin hakim olduğu bir iklimi yansıtmaktadır (Forward, Czech ve Lee, 2011). Algilanan yönetsel desteğin öğretmenlerin örgüt tarafından değer verildiklerine ve desteklendiklerine inanmalarını, görev ve sorumluluklarını yerine getirirken doğru ve dürüst olma, örgütsel süreç ve kararlara etkili katılımda ve bireysel tanınmayı (Eisenberger, Fasolo ve Lamastro, 1990) içerdiği dikkate alındığında, öğretmenlerin yönetsel destek algılarıyla savunmacı iletişim iklimi algıları arasında negatif yönlü bir ilişkinin varlığının oldukça anlamlı olduğu düşünülmektedir.

Bununla birlikte, analiz sonucunda öğretmenlerin adalet boyutunda örgütsel destek algısıyla destekleyici ve savunmacı iletişim iklimi algıları arasında yüksek düzeyde ilişki bulunduğu ve bu değişkenin yönetsel desteğe yönelik algının yanı sıra her iki iletişim iklimi algısını da yordamada önemli olduğu görülmüștür. Adalet algıs1, öğretmenlerin okul yönetiminin tüm öğretmenlere eşit mesafede durduğu, okuldaki çeşitli uygulama ve değerlendirmelerde onlara adil davrandığ 
yaptığı, sorumluluklara denk yetki verdiği, öğretmenlerin başarılarını fark ettiği ve ödüllendirdiği, öneri ve görüşlerin özgürce ifade edilmesini sağladığı ve değer verdiğine yönelik algıyı kapsamaktadır (Derinbay, 2011). Bu kapsamda öğretmenlerin adalet algısının, yöneticilerin çalışanları arasında ayrımcılık yapmadığı, onların statü ve yeterliklerine saygı duyduğu, fikirlerini özgürce ifade etmeye ve yaratıcılıklarını sergilemelerine olanak tanıdığ 1 , açık ve dürüst bir iletişimin sürecinin hakim olduğu iklimi işaret eden destekleyici iletişim iklimiyle (Özden, 2009) ilişkilenmesi manidar bir bulgu olarak kabul edilmektedir. Benzer şekilde adalet algısının, öğretmenlerin okullarındaki yöneticilerinin eleştirisel ve yargılayıcı olduğu, çalışanların düşünce, öneri ve açıklamalarını kabul etmedikleri, onları desteklemedikleri, güç ve sorumluluğun yöneticide olduğunun çeşitli şekillerde sıklıkla vurgulandığı, denetimin ön planda olduğu ve hata kabul edilmediği, çalışanların nasıl değerlendirildiğine ilişkin yeterli bilgi paylaşımının olmadığı ve dolayısıyla öğretmenlerin bilgileri, düşünce ve önerilerini kendilerine sakladığı, moral ve motivasyonun düşük olduğu, kişilerin kendini korumaya odaklandığı bir iklimi vurgulayan savunmacı iletişim iklimiyle (Özden, 2009) negatif yönlü ilişkilenmesi kabul edilebilir bir bulgu olarak görülmektedir.

İletişim iklimi, çalışanların örgütlerinin iç çevresinin kalitesini öznel yaşantıları aracılığıyla deneyimleyerek örgütlerine yönelik genel bir eğilim belirlemeleri ve bu eğilimin diğer çalışanlarla iletişim ve etkileşimleri sonucunda ortaklaşa hale gelmesi sonucunda oluşmaktadır (Çetin, 2012; Goldhaber, 1993; Moran ve Volkwein, 1992). Dolayısıyla öğretmenlerin örgütlerinin kendilerine sağladıkları desteğe yönelik algıları da dahil olmak üzere örgütlerindeki deneyimleri sonucunda okullarındaki örgütsel gerçekliğe yönelik algıları şekillenmektedir. Bu çalışmada da benzer şekilde öğretmenlerin özellikle yönetsel ve adalet boyutlarında örgütsel destek algılarının, okullarındaki iletişim iklimine yönelik algılarıyla ilişkilendiği ve hem destekleyici hem de savunmacı iletişim iklimini önemli ölçüde yordadığ 1 görülmüştür.

Diğer yandan öğretmenlerin öğretimsel destek algısının, okullarındaki destekleyici ve savunmacı iletişim iklimlerine yönelik algıları arasında anlamlı ilişki olduğu ancak her iki iletişim iklimi algısını da anlamlı düzeyde yordamadığ1 görülmüştür. Bu bulgu öğretmenlik mesleğinin profesyonel bir meslek olmasıyla ilişkilendirilebilir. Profesyonellik, bir meslek üyesinin mesleğinin gerektirdiği görevleri en üst nitelikte yapabilecek yeterlikte olması ve bununla bağlantılı olarak mesleki gelişime açık olması, kendisini sürekli geliştirmesi, bilgi, beceri ve yeteneklerini sonuna kadar kullanmasını kapsamaktadır (Altınkurt ve Yılmaz, 2011; Aydın, 2011; Gedik Dinç ve Gizir, 2019). Aydın (2011), profesyonelliğin aynı zamanda etik bir ilke olduğunu vurgulamaktadır. Bu kapsamda birer profesyonel olan öğretmenlerin mesleki bilgi, beceri ve yeteneklerini kullanmaları, mesleki gelişime açık olmaları ve kendilerini geliştirmeyi bir meslek üyesi olarak bireysel sorumlulukları olarak görüyor olabilirler. Bununla birlikte ölçme aracında okul yönetiminin öğretmenlerin fikir ve önerilerini dikkate almaması, varlığını önemsememesi, mesleki gelişimleri için herhangi bir çaba göstermemesi, başarıları takdir edip etmemesine yönelik öğretimsel desteği işaret eden maddeler aynı zamanda öğretmenlerin başarılarının fark edildiği ve ödüllendirdiği, öneri ve görüşlerin özgürce ifade edilmesinin sağlandığ ve değer verildiği, kişisel ve mesleki yeterliklere uygun görev dağılımı yapılıp yapılmadığ 1 ve onların problemleriyle ilgilenilmesine yönelik algıyı işaret eden yönetsel ve adalet algısı (Derinbay, 2011) kapsamında değerlendirilmiş olabilir. Dolayısıyla, öğretmenlerin öğretimsel destek algısını belirlemeye yönelik çalışmaların bu kapsamda değerlendirilerek yapılması gerektiğini düşünülmektedir.

Bunun yanı sıra bulguların genellemesinde, araştırma örnekleminin Hatay'da görev yapan ilköğretim öğretmenleriyle sınırlı olduğu dikkate alınmalıdır. Bu kapsamda daha büyük örneklem gruplarıyla çalışmanın tekrar edilmesinin yanı sıra araştırmacılara odaklandıkları olgular hakkında daha derinlemesine veri sağlayabilecek olan nitel çalışmalar yapılması önerilmektedir. 


\section{Kaynakça}

Ahsanul, M. I. (2013). The role of communication climate in organizational effectiveness. International Journal of Scientific \& Engineering Research, 4(7), 155-156.

Altınkurt, Y. ve Yılmaz, K. (2011). Ortaöğretim okulu öğretmenlerinin öğretmenlerin liderlik davranışlarına ilişkin görüşleri. Journal of Qafqaz University, 32, 104-113.

Aselage, J., \& Eisenberger, R. (2003). Perceived organizational support and psychological contracts: A theoretical integration. Journal of Organizational Behavior, 24, 491-509.

Aydın, İ. (2011). Ögrretmenlik meslek etiği. [Çevrim-içi: http://www.blogspot.com.09.2011], Erişim tarihi: 12.03.2016.

Barutçu, K. (2015). Катu personelinde algılanan örgütsel desteğin örgütsel bağlllık ve örgütsel özdeşleşme düzeyleri ile iliş̧kisini belirlemeye yönelik bir araştırma (Yüksek Lisans Tezi). Osmangazi Üniversitesi Sosyal Bilimler Enstitüsü, Eskişehir.

Bilir, P. F. (2005). Gençlik ve Spor Genel Müdürlüğ̈̈nün örgüt iklimi ve çalışanların katılımla ilgili algılamaları (Yayınlanmamış Doktora Tezi). Çukurova Üniversitesi, Sağlık Bilimleri Enstitüsü, Beden Eğitimi ve Spor Ana Bilim Dalı, Adana.

Book, C. L., Albrecht, T. L., Atkin, C., Bettinghaus, E. P., \& Donohue, W. A. (1980). Human communication: Principles, contexts, and skills. New York: St. Martin's.

Buchholz, W. (2001). Open communication climate. [Available online at: http://www.pdx.edu/sites/www.pdx.edu.cae/files/Workplace.pdf], Retrieved on January 06, 2017.

Büyükgöze, H. (2014). Lise ögretmenlerinin görüşlerine göre algilanan örgütsel destek ve psikolojik sermaye ilişkisi (Yüksek Lisans Tezi). Hacettepe Üniversitesi Eğitim Bilimleri Enstitüsü, Ankara.

Cohen, J. (1992). A power primer. Psychological Bulletin, 112(1), 155-159.

Costigan, I. J., \& Schmeidler, M. (1987). Exploring supportive and defensive communication climates. In J. E. Jones, \& W. Pfeiffer (Eds), The 1984 Annual Developing Human Resources (pp.112-119). San Diego, CA: University Associates.

Çetin, S. (2012). Örgütsel iletişimin değerlendirilmesi: Belediyelere dair uygulamalı bir çalışma. Çukurova Üniversitesi Sosyal Bilimler Enstitüsü Dergisi, 21(3), 185-204.

Çobanoğlu, F. ve Derinbay, D. (2011). İlköğretim okullarında görev yapan öğretmenlerin algıladıkları örgütsel destek düzeyleri. Pamukkale Üniversitesi Eğitim Fakültesi Dergisi, 40, 176-190.

Demir, M. (2012). Örgütsel destek, örgütsel bağlılık ve işten ayrılma eğilimi ilişkisi: Havalimanı yer hizmetleri işletmelerine yönelik bir araştırma. İş Güç Endüstri Illişkiler ve İnsan Kaynakları Dergisi, 14(1), 47-64.

Derinbay, D. (2011). Illköğretim okullarında görev yapan öğretmenlerin algıladıkları örgütsel destek düzeyleri (Yüksek Lisans Tezi). Pamukkale Üniversitesi, Sosyal Bilimler Enstitüsü, Denizli.

Eğriboyun, D. (2013). Ortaöğretim okullarında görev yapan yönetici ve ögretmenlerin örgütsel güven, örgütsel destek ve örgütsel bağglllkları arasındaki ilişsi, Bolu ili örneği (Doktora Tezi). Abant İzzet Baysal Üniversitesi, Eğitim Bilimleri Enstitüsü, Bolu.

Eisenberger, E. M., Fasolo, P., \& Lamastro, D. (1990). Perceived organizational support and employee diligence, commitment and innovation. Journal of Applied Psychology, 75, 51-59.

Fındıklı, A. M. (2014). Algılanan lider desteği ve algılanan örgütsel destek ile işten ayrılma niyeti ilişkisinde örgütsel özdeşleşmenin aracılık rolü: İstanbul'da kamu çalışanları üzerine bir araştırma. İ.Ü. İsletme Fakültesi İşletme İktisadı Enstitüsü Yönetim Dergisi, 25(77), 136-157.

Forward, G. L., Czech, K., \& Lee, C. M. (2011). Assessing Gibb's supportive and defensive communication climate: An examination of measurement and construct validity. Communication Research Reports, 28(1), 1-15. doi: 10.1080/08824096.2011.541360

Gedik Dinç, R. ve Gizir, S. (2019). Öğrencilerin bakış açısından öğretim elemanlarının sınıf içindeki etik dışı davranışları. Yükseköğretim Dergisi, 9(1), 29-39. doi:10.2399/yod.18.033

Gibb, J. R. (1961). Defensive communication. Journal of Communication, 11, 141-148.

Gizir, S. (2007). Üniversitelerde örgüt kültürü ve örgüt içi iletişim üzerine bir derleme çalışması. Kuram ve Uygulamada Ĕ̈itim Yönetimi, 50, 247-268.

Gizir, S. ve Köksal, E. K. (2014). İlköğretim okulu öğretmenlerinin iletişim doyumlarının incelenmesi. İn̈̈n̈̈ Üniversitesi Eğitim Fakültesi Dergisi, 15(2), 89-108. doi:10.17679/iuefd.33325

Goldhaber, G. M. (1993) Organizational communication, 6th ed. Madison: Brown \& Benchmark.

Guzley, R. M. (1992). Organizational climate and communication climate: Predictors of commitment to the organization. Management Communication Quarterly, 5, 379-402. 
Gül, Ö. (2012). Örgütsel iklim ve iletişim iklimi arasındaki etkileşim: OMU Vakfi işletmelerinde bir araştırma (Yüksek Lisans Tezi). Dumlupınar Üniversitesi, Sosyal Bilimler Enstitüsü, Kütahya.

Hassan, B., Maqsood, A., \& Riaz, N. M. (2011). Relationship between organizational communication climate and interpersonal conflict management styles. Pakistan Journal of Psychology, 42(2), 2341.

Hussein, A., \& Mohammed. R. (2013). Communication climate and organizational performances: A comparison studies between two public organizations. [Available online at: https://translate.google.com.tr/translate?hl=tr\&sl=en\&u=https://www.researchgate.net/profile/Ros li_Mohammed/publication/236133199_Communication_Climate_and_Organizational_Performan ces/links/0c96051642aece7bef000000\&prev=search], Retrieved on January 01, 2017.

Keenan, J. P. (1988). Communication climate, whistle-blowing and the first level manager: A preliminary study. Academy of Management Proceedings, 5, 247-251.

Kowalski, T. J. (2000). Cultural change paradigms and administrator communication. Contemporary Education, 71(2), 4-12.

Larsen, S., \& Folgero, S. I. (1993). Supportive and defensive communication. International Journal of Contemporary Hospital Management, 5(3), 22-25.

Moran, T. E., \& Volkwein, F. S. (1992). The cultural approach to the formation of organizational climate. Human Relations, 45, 19-47.

Ökten, B. (2015). Algılanan örgütsel destek ve psikolojik sahiplenme arasındaki ilişki ve bu ilişkide örgütsel adaletin rolü. Hacettepe Üniversitesi İktisadi ve İdari Bilimler Fakültesi Dergisi, 33(2), 113-140.

Özden, T. (2009). Illköğretim okullarında çalışan ögretmenlerin okullarındaki iletişim iklimine yönelik algıları (Yüksek Lisans Tezi). Mersin Üniversitesi, Sosyal Bilimler Enstitüsü, Mersin.

Özden, T. ve Gizir, S. (2013). İlköğretim okulu ögretmenlerinin okullarındaki iletişim iklimine yönelik algılarının incelenmesi. Eğitim Yöneticileri ve Uzmanları Derneği ve Balıkesir Üniversitesi tarafından 03-05 Ekim 2013 tarihinde Balıkesir/Burhaniye'de düzenlenen EYFOR - IV Eğitim Yönetimi Forumu'nda sözlü bildiri olarak sunulmuş ve tam metin olarak yayınlanmıştır.

Robertson, E. (2003). How to use a communication climate model. Strategic Communication Management, 7, 24-27.

Smidts, A., Pruyn, H., \& VanRiel, M. (2001). The impact of employee communication and perceived external prestige on organizational identification. Academy of Management Journal, 49, 10511062.

Trobbetta, J., \& Rogers, D. P. (1988). Communication climate, job satisfaction and organizational commitment. Management Communication Quarterly, 1, 497-514.

Turgut, H. (2014). Algılanan örgütsel desteğin işletme performansına etkisinde iç girişimciliğin aracılık rolü. İsletme Araştırmaları Dergisi, 6(3), 29-62.

Ulukuş, K. S. (2010). Örgütsel iletişim örüntüsünün kurum içi ilişkilerdeki önemi: Aksaray Il Emniyet Teşkilatında uygulamalı bir çalışma (Doktora Tezi). Selçuk Üniversitesi, Sosyal Bilimler Enstitüsü, Konya.

Welsch, H. P., \& LaVan, H. (1981). Inter-relationships between organizational commitment and job characterstics, job satisfaction, professional behaviour and organizational climate. Human Relations, 34, 1079-1089.

Yüksel, İ. (2006). Örgütsel destek algııı ve belirleyicilerinin işten ayrılma eğilimi ile ilişkisi. İstanbul Üniversitesi Işletme Fakültesi Dergisi, 35(1), 7-32. 


\section{Extended Abstract}

\section{Introduction}

Communication climate of an organization reflects its members' perceptions on the general features of communication process in their organizations (Gizir \& Köksal, 2014). Communication climate is classified as supportive and defensive communication climate by focusing on interactions and communication among organizational members, and between the members and leaders (Costigan \& Schmeidler, 2001). A supportive climate reflecting supportive environment in an organization has six characteristics, namely empathy, provisionalism, equality, problem orientation, spontaneity, and description while a defensive climate has six characteristics, called evaluation, strategy, control, superiority, neutrality, and certainty. Open exchange of information, worker participation, and constructive conflict resolution are seen as main characteristics of an organizational with supportive communication, while leaders act in a manipulative, judgmental, critical, and an authoritarian manner toward employees, closely watch over the work of them, effort to change them, and lead them to feel inadequate in organizations in defensive climate (Costigan \& Schmeidler, 2001; Gizir \& Köksal, 2014).

Communication climate is associated with many organizational behaviors such as job satisfaction, loyalty, organizational climate, conflict, performance, efficiency, trust and motivation (Gül, 2012; Hassan, Maqsood ve Riaz, 2011; Ulukuş, 2012). Moreover, it was observed in the related literature that employees' needs and expectations such as to be committed to their organizations, to have a high motivation, to be able to do their jobs with interest and motivation, to be able to increase their performance, to be approved, to be valued, to be supported when doing their jobs should be met, because employees' perception of meeting their needs and expectations reflects their perceived organizational support.

Aselage and Eisenberger (2003) consider the perception of organizational support as the psychological agreement that the employees have made with the organization in which their works. It is stated that the organization will provide adequate service and benefit to the employer by fulfilling this agreement and that the employee will exhibit positive attitude and organizational behaviors in the organizational environment (Barutçu, 2015; Büyükgöze, 2014). Based on the related literature, it was proposed that organizational support to employees and employees' perception of this support can be associated with their perception of organizational communication climate. Literature review also indicated that there were a number of studies about teachers' perception of organizational support including three sub-dimensions called instructional support, administrative support and justice, and limited studies on the perception of communication climate in their schools while there was not any study focusing on the relationship between the teachers' perceived organizational support and the perception of communication climate. Considering the importance of teachers' perceived organizational support and also their perception of communication climate in their schools on their organizational behaviors, this study aims at determining the role of teachers' perceptions of organizational support on their perception of communication climate in their schools.

\section{Method}

The sample of the study was consisted of 405 teachers employed 42 primary and secondary schools in the province of Hatay in Turkey. Out of 405 teachers, 222 (\% 54.8) were famale, 183 (\%45.2) male, and also 115 were classroom teachers (\%28.4), 290 were subject matter teachers (71.6\%). The Communication Climate Inventory developed by Costigan and Schmeidler (2001), 
and adopted into Turkish by Özden (2009) was used to gather the data from the sample. For measuring the teachers' perceived support, The Perceived Organizational Support Scale (Çobanoğlu \& Derinbay, 2011) including three sub-dimensions, namely instructional support, administrative support and justice was used. The data were gathered from the sample analyzed by using multiple regression.

\section{Result and Discussion}

The results revealed that there are significant correlations between all sub-dimensions of the perceived organizational support, and the supportive and defensive communication climate. Furthermore, the results showed that teachers' perceived administrative support and justice which are the sub-dimensions of perceived organizational support are important variables in predicting teachers' perceptions on supportive and defensive communication climates in their schools. On the other hand, it was observed that the sub-dimensions of the instructional support did not significantly predict teachers' perceptions on supportive and defensive communication climate in their schools. So, it seems to be acceptable that teachers' perceptions on whether their schools meet their needs and expectations such as to be approved, to be valued, to be respected, to be supported when doing their jobs, to be supervised when they need, to notice their professional ideas and experiences lead them to perceive communication climate in their schools are supportive or defensive. 